\title{
COMPARISON STUDY OF BUPIVACAINE, LEVOBUPIVACAINE AND ROPIVACAINE IN AXILLARY BRACHIAL PLEXUS BLOCK: A CLINICAL STUDY
}

\author{
Shikha Mehrotra1 ${ }^{1}$ Hansraj Baghel2 ${ }^{2}$ Deepesh Gupta ${ }^{3}$ \\ ${ }_{1}^{1}$ Professor, Department of Anaesthesia, Gandhi Medical College, Bhopal. \\ ${ }^{2}$ Former Post Graduate Student, Department of Anaesthesia, Gandhi Medical College, Bhopal. \\ ${ }^{3}$ Associate Professor, Department of Anaesthesia, Gandhi Medical College, Bhopal.
}

ABSTRACT

$\overline{\text { AIM }}$

Aim of our study was to assess effect of $0.5 \%$ bupivacaine, $0.5 \%$ levobupivacaine and $0.5 \%$ ropivacaine in axillary brachial plexus block.

\section{OBJECTIVE}

To compare the onset time and duration of sensory and motor blockade of $0.5 \%$ bupivacaine, $0.5 \%$ levobupivacaine and $0.5 \%$ ropivacaine in axillary brachial plexus.

\section{MATERIAL AND METHOD}

Ninety patients of ASA I and II of age group 20yrs-60yrs of either sex were included in our study undergoing upper limb surgeries in Gandhi Medical College and Hamidia Hospital, Bhopal (MP). The patients were randomly divided into three groups:- Group I (n= 30) : Bupivacaine $0.5 \%-5 \mathrm{mg} / \mathrm{ml}-30 \mathrm{ml}$, Group II $(\mathrm{n}=30)$ : Levobupivacaine $0.5 \%-5 \mathrm{mg} / \mathrm{ml}--30 \mathrm{ml}$, Group III (n=30) : Ropivacaine $0.5 \%-5 \mathrm{mg} / \mathrm{ml} \mathrm{--} 30 \mathrm{ml}$ onset time of sensory and motor block, duration of sensory and motor block and duration of pain relief were recorded.

\section{RESULT}

Analysis revealed that Ropivacaine provided fast onset of action and better quality of anaesthesia and analgesia than bupivacaine and levobupivacaine when used in axillary brachial plexus blockade. There was no significant difference in duration of sensory blockade between three groups. But Ropivacaine showed lesser duration of motor blockade when compared to bupivacaine and levobupivacaine.

\section{CONCLUSION}

We conclude that $0.5 \% 30 \mathrm{ml}$ of ropivacaine in axillary brachial plexus block is a safe dose, allowing practitioner to produce a fast onset of sensory block and long duration of peripheral nerve block with excellent postoperative analgesia and stable hemodynamics. So ropivacaine is a better option for forearm surgeries in axillary brachial plexus block when compared with bupivacaine and levobupivacaine.

\section{KEYWORDS}

Axillary Block, Ropivacaine, Bupivacaine.

HOW TO CITE THIS ARTICLE: Shikha Mehrotra, Hansraj Baghel, Deepesh Gupta. "Comparison Study of Bupivacaine, Levobupivacaine and Ropivacaine in Axillary Brachial Plexus Block: A Clinical Study." Journal of Evolution of Medical and Dental Sciences 2015; Vol. 4, Issue 102, December 21; Page: 16717-16722, DOI: 10.14260/jemds/2015/2502

\section{INTRODUCTION}

For over a century, brachial plexus anesthesia has been an indispensable tool in the anesthesiologist's armamentarium. Axillary block of the brachial plexus is a common, simple and safe anaesthetic technique for distal upper extremity surgery; often for elbow, forearm and hand surgery. Different techniques can be used to achieve block on using perivascular approach to brachial plexus.[1,2,3] Bupivacaine, ropivacaine and levobupivacaine are commercially available intermediateacting LAs. They have some differences in risk of cardiovascular and CNS toxicity, but they have similar anesthetic and analgesic potency.[4,5]

Financial or Other, Competing Interest: None.

Submission 08-12-2015, Peer Review 09-12-2015,

Acceptance 15-12-2015, Published 18-12-2015.

Corresponding Author:

Dr. Hansraj Baghel,

BTI and Bharoli Road Tiraha

Vishal Nagar, Bhind-477001,

Madhya Pradesh.

E-mail: dr.hansrajbaghel@gmail.com

DOI:10.14260/jemds/2015/2502
Levobupivacaine is a long-acting local anaesthetic with a clinical profile closely resembling that of bupivacaine.(6)

It is a relatively new long-acting local anesthetic that have been developed after reports of simultaneous seizure and cardiac arrest with prolonged resuscitation after accidental intravascular injection of bupivacaine.(7)

The use of levobupivacaine is described for peripheral nerve blocks besides epidural, caudal and spinal anesthesia and the agent is used for all common indications in a wide range of clinical settings. ${ }^{(8,9)}$

Regional anaesthesia is becoming increasingly popular for orthopaedic surgery as it offers several advantages over general anaesthesia and a trend towards more peripheral and selective nerve blocks exists.(10)

By this aim for upper limb surgery interscalene blocks are ideally suited for shoulder and upper arm surgery, supraclavicular nerve blocks for upper arm, elbow and radial side of forearm and the infraclavicular and axillary block are suited for hand, wrist and forearm surgery.(2)

Since then axillary block of the brachial plexus is a suitable anaesthetic technique both for orthopaedic, plastic 
and peripheral vascular surgery procedures performed distal to the elbow. Also in emergency surgery, axillary brachial plexus blocks represent more than $50 \%$ of all regional anesthesia techniques performed with mid-humeral brachial plexus block.(11)

\section{MATERIAL AND METHODS}

After obtaining informed consent and approval of the institutional ethics committee, this prospective randomized study was conducted on 90 patients of ASA I and II of age group 20yrs-60yrs of either sex were admitted to Hamidia Hospital for elective upper limb surgeries.

\section{The Patients Were Randomly Divided into three Groups Group I $(\mathrm{n}=30)$ : Bupivacaine $0.5 \%-5 \mathrm{mg} / \mathrm{ml}--30 \mathrm{ml}$ Group II ( $\mathrm{n}=30)$ : Levobupivacaine $0.5 \%-5 \mathrm{mg} / \mathrm{ml} \mathrm{--} 30 \mathrm{ml}$ Group III ( $\mathrm{n}=30)$ : Ropivacaine $0.5 \%-5 \mathrm{mg} / \mathrm{ml} \mathrm{--30 \textrm {ml }}$} Proper preanesthetic checkup of all patients was done. All routine investigation like CBP, urine (Routine and microscopic), blood urea, blood sugar, ECG (in $>40 \mathrm{yrs}$ ) and relevant specific investigation was done.

\section{Selection Criteria}

- Patients of age group 20yrs-60yrs of ASA I and II physical status.

\section{Exclusion Criteria}

- Patient with history of cardiopulmonary, neurologic, active hepatic and renal diseases, psychiatric disorders.

- Pregnant and lactating women.

- Contraindication for brachial plexus block such as coagulation disorders, cutaneous local infection.

- Sensitive to local anaesthetic agents.

- Patients who were not willing for regional block.

\section{INTRAOPERATIVE MONITORING}

Pulse rate, blood pressure, respiratory rate, oxygen saturation, ECG, the onset and duration of sensory and motor blockade were monitored every 5 minutes up to first 30 minutes, then every 15 minutes up to $1 \mathrm{hr}$. and then at hourly interval up to 6hrs, then 2 hourly up to $12 \mathrm{hrs}$. Complications and side effects of local anaesthetic were closely observed.

\section{Monitoring Included Following Points \\ 1. Onset of sensory and motor block. \\ 2. Duration of sensory and motor block. \\ 3. Need for any supplement analgesia. \\ 4. Complications if any.}

Sensory Block in the Surgical Procedure Planned Site was Tested by Using the Pinprick Test and Compared with the Same Stimulation in the Contralateral Hand

1. Normal sensitivity-0(no block).

2. Reduced sensitivity compared with the same territory in the contralateral upper limb-1(onset).

3. Analgesia or loss of the sharp sensation of the pinprick-2 (Partial).

4. Anaesthesia or loss of sensation to touch -3 (Complete).

Motor Block was Assessed According to the Following Scale

1. No block-0.
2. Decreased movement with loss of strength-1 (Onset).

3. Decreased movement with inability to perform movement against resistance-2 (Partial).

4. Paralysis-3 (Complete).

Patient were considered ready for surgery when score reached 2 (Partial sensory and motor). Time to Onset of sensory block (Minute): Time between the end of injection and the total abolition of the pinprick response and complete paralysis in all of nerve distributions. Time to onset of motor block (Minute): Time to reach score of 1 . First analgesic requirement time (Minute): Time interval between block placement and patients, first analgesic request.

According to need for supplementary intravenous analgesia, the quality of nerve block will be evaluated as follows

- Satisfactory nerve block - No supplemental analgesia required to complete surgery.

- Unsatisfactory nerve block - Fentanyl supplementation required to complete surgery.

- Failed nerve block - TIVA or GA required to complete surgery.

\section{Postoperative Observations}

- At the end of surgery, the residual effects and duration of surgery were noted after shifting to the ward. Patient was visited for the assessment of postoperative analgesia, any complications and for monitoring of vital parameters at defined time interval.

- Postoperative analgesia assessed on 10 point of visual analogue scale.

- Visual analogue scale, $0=$ No pain

$10=$ Worst pain

- Duration of postoperative analgesia $=$ Time from onset of sensory blockade to time when patient VAS score was $>5$.

\section{ASSESSMENT OF COMPLICATIONS AND SIDE EFFECTS}

A careful watch was kept for the complication such as,

- Respiratory system-Respiration insufficiency.

- Cardiovascular system-Bradycardia and hypotension.

- Central nervous system-Headache, convulsion.

- Gastrointestinal system-Nausea and vomiting.

- Local complications-Hematomas.

- Allergic complications-Pruritis, itching etc.

The statistical significant difference among the groups was assessed by the use of one way ANOVA test, Z-test and Chisquare test. Differences were considered significant at $\mathrm{p}<0.05$.

\section{RESULT AND ANALYSIS}

In this study, we observed that most of the patients are between the age group of 20-30 years and male in all three groups. (Table 1 and 2). Duration of most of the surgeries is almost same. Group I-87 min, group II-78.2 min and in group III-74.2 min. (Table 3) The onset time of sensory block in group I -16.6 min, group II-15.6 min and group III-13.7 $\mathrm{min}$ (I>II>III). The duration of sensory block in group I-655.5 min, group II$614 \mathrm{~min}$ and in group III-631.5 min (I>III>II). It was found statistically significant ( $\mathrm{p}$ value $<0.05$ ). (Table 4A, 4B and 4C).

The onset time of motor block in group I -12.6 min, group II-11.6 min and group III -10.3 min (I>II > III). The duration of 
motor block in group I-636.2 $\mathrm{min}$, group II-595.7 $\mathrm{min}$ and in group III-560 min (I>II $>$ III). It was found statistically significant ( $\mathrm{p}$ value $<0.05$ ). (Table $5 \mathrm{~A}, 5 \mathrm{~B}$ and $5 \mathrm{C}$ ).

Duration of pain relief in group I-654.8 min, group II$614.7 \mathrm{~min}$ and group III-631.5 $\mathrm{min}$ (I>III $>$ II). It was found statistically significant ( $\mathrm{p}$ value $<0.05$ ). (Table $6 \mathrm{~A}$ and $6 \mathrm{~B}$ ) Mostly patients required a single dose of analgesic in $24 \mathrm{hr}$ in all groups. (Table-7) No complication occurs in all three groups. (Table-8) Pulse rate, systolic blood pressure and diastolic blood pressure are almost same in all three groups. Statistically insignificant ( $\mathrm{p}$ value $>0.05$ ). (Table 9, 10 and 11).

\section{DISCUSSION}

Importance of regional anaesthesia has increased in recent years. Regional anaesthesia for central neural blockade as well as blockade of peripheral nerves and plexus has become a vital part of present clinical practice of anesthesiologist. However, toxicity issues have tarnished the history of regional anaesthesia and although great improvements have been made.

Besides being well tolerated and safe, an ideal regional anesthetic agent should have short time of onset and lead to profound sensory and motor blockade of sufficient duration adequate for the indication or procedure.

In our study we used $0.5 \%$ of ropivacaine, $0.5 \%$ of levobupivacaine and $0.5 \%$ bupivacaine for brachial plexus blockade.

Our study was in accordance with Hickey R, Hoffman J, S Ramanuthy (1991).[12] Our study was also in accordance with McGlade DP, Kalokas, Moeney PH, Chambey D (1998).[13] and Klein SM, Greengrass RA, Grant SA, et al. (2001).[14]

In our study, we used $30 \mathrm{ml}$ of drug volume for all the three groups. Our study was in accordance with Klein SM, Greengrass RA, Grant SA (2001).[14] used $30 \mathrm{ml}$ of $0.75 \%$ and $0.5 \%$ ropivacaine and $0.5 \%$ bupivacaine for comparison in interscalene brachial plexus block.

In our study, the mean time of onset of sensory blockade was 16.6 mins in-group I, for group II mean onset time of sensory blockade was 15.6 mins and for group III it was 13.7 and time of onset of motor blockade for group I was 12.6 \pm 1.8 mins, for group II it was 11.6 and for group III it was $10.3 \pm 1.6$ mins.

Our study was in accordance with Hickey R, Condido KD, Ramamurthy S (1990).[15] compared 0.5\% ropivacaine with and without epinephrine in conc of 1:200,000 in subclavian perivascular brachial plexus block for upper extremity surgeries found rapid initial onset of sensory and motor block (a mean of less than 4 min for analgesia). They found that the addition of epinephrine did not significantly affect the onset of sensory or motor block.

Our study was also in accordance with Casati A, Fanelli G, Cappellari G (1999).[16] Nagia Mohammed Abd El Morti, Zeinab Bayoumy Youssef, Soaad Said Abd El Aal (2006).[17] and Bertini L, Tagariello V, Mancini S, Ciaschi A, Posteraro CM (1999).[18]

In our study, the mean duration of sensory and motor blockade of group I were 655.5 mins and 636.2 mins, that of group II were 614.7 mins and 595.7 mins and that of group III were $631.5 \mathrm{~min}$ and $560.5 \mathrm{~min}$ and $\mathrm{P}$ value for duration of sensory block was $>0.05$ and not statistically significant, but for duration of motor block $\mathrm{P}$ value was $<0.05$ which was statistically significant.

Our study was similar with Raeder JC (1999).[19] also observed that there was no difference in duration of blockade
(9-11 hours) when ropivacaine $7.5 \%$ and bupivacaine $0.5 \%$ used for axillary brachial blockade.

Our study was also in accordance with Hickey R, Hoffman J, S Ramamurthy (1991).[12] and Klein SM, Greengrass RA, Grant SA (2001).[14]

In our study, the mean duration of analgesia was $654.8 \pm 37.6$ mins in group I, $614.7 \pm 33.6$ in group II and $631.5 \pm 32.7$ mins in group III and P value was $>0.05$ and not significant statistically.

Our study was similar with Casati A, Albertin (2000).[19] studied $0.5 \%$ ropivacaine and $0.5 \%$ bupivacaine for interscalene brachial plexus block and observed duration of analgesia $11 \pm 5 \mathrm{hrs}$ after $0.5 \%$ ropivacaine and $10.9 \pm 3.9 \mathrm{hrs}$ after $0.5 \%$ bupivacaine.

Our study was also in accordance with Hickey R, Candido KD (1990).[15] Hickey R, Hoffman J, Ramamurthy 1991.[12] and Casati A, Fanelli G, Cappelleri (1999).[16]

In our study mean heart rate, systolic blood pressure, SPO2 and respiratory rate all remained within the normal limit after the block in all the three groups and were not significant statistically ( $p>0.05)$.

Our study was similar with McGlade DP (1998).[13] observed no significant changes in vital parameter when studied $0.5 \%$ ropivacaine and $0.5 \%$ bupivacaine for axillary brachial block.

Our study was also in accordance with Hickey R, Candido KD (1990).[15]

Hickey R, S Ramamurthy (1991).[12] and Casati A, Albertin A (2000).[20]

In our study, no complication occurs in all three groups. Our study was similar with Hickey R, Hoffman J, S Ramamurthy (1991).[12] Raeder JC (1999).[19] and Eroglu A, Uzunlar H (2004).[21]

Thus, in our study most of the observations were in accordance with various studies conducted in the past and mentioned above. In our study onset of action of block with ropivacaine was faster than that of bupivacaine and levobupivacaine and was statistically significant. The duration of motor blockade with ropivacaine was less than that of bupivacaine and levobupivacaine and was statistically significant.

\section{CONCLUSION}

We conclude that $0.5 \%, 30 \mathrm{ml}$ of ropivacaine in axillary brachial plexus block is a safe dose, allowing practitioner to produce a fast onset of sensory block and long duration of peripheral nerve block with excellent postoperative analgesia and stable hemodynamics. So ropivacaine is a better option for forearm surgeries in axillary brachial plexus block when compared with bupivacaine and levobupivacaine.

\begin{tabular}{|c|c|c|c|c|}
\hline \multirow{2}{*}{ Age in Years } & \multicolumn{3}{|c|}{ Groups } & \multirow{2}{*}{ Total } \\
\cline { 2 - 4 } & I & II & III & \\
\hline $20-30$ & 17 & 14 & 16 & 47 \\
\hline $31-40$ & 10 & 10 & 9 & 29 \\
\hline $41-50$ & 3 & 5 & 3 & 11 \\
\hline $51-60$ & 0 & 1 & 2 & 3 \\
\hline Total & 30 & 30 & 30 & 90 \\
\hline $\begin{array}{r}\text { Table 1: Showing Demographic Profile of Patients in } \\
\text { Three Groups (Age wise Distribution of Cases) }\end{array}$ \\
\hline
\end{tabular}




\begin{tabular}{|c|c|c|c|c|}
\hline \multirow{2}{*}{ SEX } & \multicolumn{3}{|c|}{ Groups } & \multirow{2}{*}{ Total } \\
\cline { 2 - 4 } & I & II & III & \\
\hline Female & $5(16.7 \%)$ & $7(23.3 \%)$ & $7(23.3 \%)$ & 19 \\
\hline Male & $25(83.3 \%)$ & $23(76.7 \%)$ & $23(76.7 \%)$ & 71 \\
\hline Total & $\mathbf{3 0}$ & $\mathbf{3 0}$ & $\mathbf{3 0}$ & $\mathbf{9 0}$ \\
\hline \multicolumn{4}{|c|}{$\begin{array}{r}\text { Table 2: Demographic Profile of Patients } \\
\text { (Sex wise Distribution of Cases) }\end{array}$} \\
\hline
\end{tabular}

\begin{tabular}{|c|c|c|c|c|c|c|}
\hline & \multicolumn{2}{|c|}{ GROUP I } & \multicolumn{2}{c|}{ GROUP II } & \multicolumn{2}{c|}{ GROUP III } \\
\cline { 2 - 7 } & Mean & $\mathbf{\pm S D}$ & Mean & $\mathbf{\pm S D}$ & Mean & $\mathbf{\pm S D}$ \\
\hline $\begin{array}{c}\text { Duration } \\
\text { of Surgery } \\
\text { (Min) }\end{array}$ & 87.0 & 31.7 & 78.2 & 33.9 & 74.2 & 25.0 \\
\hline \multicolumn{6}{|c|}{ Table 3: Showing Time Duration of Surgery (Min) } \\
Among Three Groups \\
\hline
\end{tabular}

\begin{tabular}{|c|c|c|c|c|c|c|}
\hline & \multicolumn{2}{|c|}{ I } & \multicolumn{2}{|c|}{ II } & \multicolumn{2}{|c|}{ III } \\
\hline & Mean & \pm SD & Mean & \pm SD & Mean & \pm SD \\
\hline $\begin{array}{l}\text { Sensory } \\
\text { Block, } \\
\text { Onset } \\
\text { (Min) }\end{array}$ & 16.6 & 1.5 & 15.6 & 1.6 & 13.7 & 1.7 \\
\hline $\begin{array}{l}\text { Sensory } \\
\text { Block, } \\
\text { Duration } \\
\text { (Min) }\end{array}$ & 655.5 & 36.4 & 614.7 & 33.6 & 631.5 & 32.7 \\
\hline
\end{tabular}

Table showing mean \pm SD of onset and duration of sensory blockade. Onset time was $16.6 \pm 1.5 \mathrm{~min}$ in Group I, $15.6 \pm 1.6 \mathrm{~min}$ in Group II and $13.7 \pm 1.7 \mathrm{~min}$ in Group III. Duration of sensory blockade is $655.5 \pm 36.4$ min in Group I, 614.7 \pm 33.6 min in Group II and 631.5 \pm 32.7 min in Group III.

\begin{tabular}{|c|c|c|}
\hline $\begin{array}{c}\text { Comparison between } \\
\text { Groups }\end{array}$ & P value & Significance \\
\hline I and II & 0.45 & Significant \\
\hline II and III & $<0.001$ & Highly significant \\
\hline I and III & $<0.001$ & Highly significant \\
\hline Table 4 (B): Sensory Block, Onset (Min) Anova [F=26.09] \\
\hline
\end{tabular}

Table showing intergroup analysis of sensory block onset (P value) in three groups. It was found to be significant $(p<0.05)$ between three groups.

\begin{tabular}{|c|c|c|}
\hline $\begin{array}{c}\text { Comparison between } \\
\text { Groups }\end{array}$ & P value & Significance \\
\hline I and II & $<0.001$ & Significant \\
\hline II and III & 0.18 & Not significant \\
\hline I and III & 0.024 & Significant \\
\hline Table 4 (C): Sensory Block, Duration \\
(Min) Anova [F=10.7] \\
\hline
\end{tabular}

Table showing intergroup analysis of sensory block duration ( $\mathrm{P}$ value) in three groups.

It was found to be significant $(\mathrm{p}<0.05)$ between groups I and II and groups I and III, but it was insignificant $(\mathrm{p}>0.05)$ between groups II and III.

\begin{tabular}{|c|c|c|c|c|c|c|}
\hline & \multicolumn{2}{|c|}{ GROUP I } & \multicolumn{2}{c|}{ GROUP II } & \multicolumn{2}{c|}{ GROUP III } \\
\cline { 2 - 7 } & Mean & $\mathbf{\pm S D}$ & Mean & $\mathbf{\pm S D}$ & Mean & $\mathbf{\pm S D}$ \\
\hline $\begin{array}{l}\text { Motor } \\
\text { Block }\end{array}$ & 12.6 & 1.8 & 11.6 & 1.8 & 10.3 & 1.6 \\
\hline
\end{tabular}

\begin{tabular}{|c|l|l|l|l|l|l|}
\hline $\begin{array}{c}\text { Onset } \\
\text { (Min) }\end{array}$ & & & & & & \\
\hline $\begin{array}{c}\text { Motor } \\
\text { Block } \\
\text { Duration } \\
\text { (Min) }\end{array}$ & 636.2 & 39.5 & 595.7 & 32.6 & 560.5 & 39.8 \\
\hline Table 5 (A): Showing Comparision of Motor Blockade \\
(Min) Among Three Groups \\
\hline
\end{tabular}

Table showing mean \pm SD of onset and duration of motor blockade.

The onset of motor block was $12.6 \pm 1.8 \mathrm{~min}$ in Group I, $11.6 \pm 1.8 \mathrm{~min}$ in Group II, and 10.3 $\pm 1.6 \mathrm{~min}$ in Group III. The duration of motor blockade (Mean \pm SD) was found to be $636.2 \pm 39.5 \mathrm{~min}$ in Group I, 595.7 $\pm 32.6 \mathrm{~min}$ in Group II and $560.5 \pm 39.8 \mathrm{~min}$ in Group III.

\begin{tabular}{|c|c|c|}
\hline $\begin{array}{c}\text { Comparison between } \\
\text { Groups }\end{array}$ & P value & Significance \\
\hline I and II & 0.065 & Not significant \\
\hline II and III & 0.014 & Significant \\
\hline I and III & $<0.001$ & Highly significant \\
\hline Table 5 (B): Motor Block, Onset (Min) Anova [F=13.7] \\
\hline
\end{tabular}

Table showing intergroup analysis of motor block onset (P value) among three groups.

It was found to be significant $(\mathrm{p}<0.05)$ between groups II and III and groups I and III, but it was insignificant $(\mathrm{p}>0.05)$ between groups I and II.

\begin{tabular}{|c|c|c|}
\hline $\begin{array}{c}\text { Comparison between } \\
\text { Groups }\end{array}$ & P value & Significance \\
\hline I and II & $<0.001$ & Highly significant \\
\hline II and III & 0.001 & Significant \\
\hline I and III & $<0.001$ & Highly significant \\
\hline
\end{tabular}

Table 5 (C): Motor Block, Duration (Min) Anova [F=30.7]

Table showing intergroup analysis of motor block duration ( $\mathrm{P}$ value) between three groups. It was found to be significant $(p<0.05)$ between three groups.

\begin{tabular}{|c|c|c|c|c|c|c|}
\hline & \multicolumn{2}{|c|}{ GROUP I } & \multicolumn{2}{|c|}{ GROUP II } & \multicolumn{2}{|c|}{ GROUP III } \\
\hline & Mean & \pm SD & Mean & \pm SD & Mean & \pm SD \\
\hline $\begin{array}{c}\text { Duration } \\
\text { of Pain } \\
\text { Relief } \\
\text { [Min] }\end{array}$ & 654.8 & 37.6 & 614.7 & 33.6 & 631.5 & 32.7 \\
\hline Table 6 & :Sho & $g D u$ & on & ain & $\operatorname{lief}(1$ & \\
\hline
\end{tabular}

Table showing mean \pm SD of duration of pain relief among three groups. It was $654.8 \pm 37.6 \mathrm{~min}$ in group I, $614.7 \pm 33.6 \mathrm{~min}$ in group II and $631.5 \pm 32.7 \mathrm{~min}$ in group III.

\begin{tabular}{|c|c|c|}
\hline $\begin{array}{c}\text { Comparison between } \\
\text { Groups }\end{array}$ & P value & Significance \\
\hline I and II & $<0.001$ & $\begin{array}{c}\text { Highly } \\
\text { significant }\end{array}$ \\
\hline II and III & 0.19 & Not significant \\
\hline I and III & 0.032 & Significant \\
\hline \multicolumn{2}{|c|}{ Table 6 (B): Duration of Pain } \\
Relief Minutes Anova [F=10.1]
\end{tabular}

Table showing intergroup analysis of duration of pain relief ( $P$ value) between three groups. It was found to be significant between groups I and II and groups I and III, but it was insignificant between groups II and III. 


\begin{tabular}{|c|c|c|c|c|}
\hline $\begin{array}{c}\text { No. of Analgesic } \\
\text { doses required } \\
\text { in first 24 hrs. }\end{array}$ & $\begin{array}{c}\text { GROUP } \\
\text { I }\end{array}$ & $\begin{array}{c}\text { GROUP } \\
\text { II }\end{array}$ & $\begin{array}{c}\text { GROUP } \\
\text { III }\end{array}$ & Total \\
\hline $\mathbf{0}$ & 8 & 7 & 5 & 20 \\
\hline $\mathbf{1}$ & 18 & 19 & 20 & 57 \\
\hline $\mathbf{2}$ & 4 & 4 & 5 & 13 \\
\hline Total & $\mathbf{3 0}$ & $\mathbf{3 0}$ & $\mathbf{3 0}$ & $\mathbf{9 0}$ \\
\hline \multicolumn{4}{|r|}{ Table 7: Showing no. of Analgesic Doses } \\
required in First 24 Hours \\
\hline
\end{tabular}

\begin{tabular}{|c|c|c|c|c|}
\hline Complications & $\begin{array}{c}\text { GROUP } \\
\text { I }\end{array}$ & $\begin{array}{c}\text { GROUP } \\
\text { II }\end{array}$ & $\begin{array}{c}\text { GROUP } \\
\text { III }\end{array}$ & Total \\
\hline NIL & 28 & 27 & 28 & 83 \\
\hline Nausea & 1 & 2 & 2 & 5 \\
\hline Vomiting & 1 & 1 & 0 & 2 \\
\hline Total & $\mathbf{3 0}$ & $\mathbf{3 0}$ & $\mathbf{3 0}$ & $\mathbf{9 0}$ \\
\hline \multicolumn{6}{|r}{ Table 8: Showing Complications in Three Groups } \\
\hline
\end{tabular}

\begin{tabular}{|c|c|c|c|c|c|c|}
\hline \multirow{2}{*}{ Pulse Rate Mean } & \multicolumn{2}{|c|}{ GROUP I } & \multicolumn{2}{c|}{ GROUP II } & \multicolumn{2}{c|}{ GROUP III } \\
\cline { 2 - 6 } & Mean & $\mathbf{\pm S D}$ & Mean & $\mathbf{\pm S D}$ & Mean & $\mathbf{\pm S D}$ \\
\hline Baseline & 83.50 & 12.328 & 82.90 & 11.096 & 81.03 & 9.782 \\
\hline $5 \mathrm{Min}$ & 82.40 & 12.588 & 82.47 & 10.605 & 81.00 & 8.971 \\
\hline $10 \mathrm{Min}$ & 82.20 & 11.294 & 82.60 & 9.673 & 81.33 & 8.539 \\
\hline $15 \mathrm{Min}$ & 80.60 & 9.974 & 82.20 & 10.162 & 81.47 & 8.468 \\
\hline $30 \mathrm{Min}$ & 81.20 & 9.932 & 81.67 & 9.338 & 81.10 & 8.248 \\
\hline $45 \mathrm{Min}$ & 79.80 & 9.253 & 81.80 & 10.284 & 80.30 & 8.595 \\
\hline $60 \mathrm{Min}$ & 79.13 & 8.366 & 81.53 & 10.044 & 79.87 & 8.220 \\
\hline $90 \mathrm{Min}$ & 79.20 & 7.622 & 80.73 & 9.833 & 80.20 & 8.193 \\
\hline $120 \mathrm{Min}$ & 79.00 & 7.944 & 80.30 & 9.531 & 79.67 & 8.438 \\
\hline 6 Hrs. & 78.30 & 7.042 & 80.50 & 9.479 & 80.20 & 7.832 \\
\hline $12 \mathrm{Hrs}$. & 80.20 & 7.494 & 80.70 & 10.120 & 80.07 & 7.728 \\
\hline 18 Hrs. & 79.93 & 7.638 & 81.53 & 9.794 & 80.53 & 7.736 \\
\hline 24 Hrs. & 81.37 & 8.215 & 81.37 & 8.798 & 81.00 & 7.786 \\
\hline Table 9: Showing Statistical Analysis of Pulse Rate (Per/Min) Among Three Groups \\
\hline
\end{tabular}

Table showing pulse rate (Mean \pm SD) at different intervals in all the three groups.

\begin{tabular}{|c|c|c|c|c|c|c|}
\hline \multirow{2}{*}{ SBP } & \multicolumn{2}{|c|}{ GROUP I } & \multicolumn{2}{|c|}{ GROUP II } & \multicolumn{2}{|c|}{ GROUP III } \\
\hline & Mean & \pm SD & Mean & \pm SD & Mean & \pm SD \\
\hline Baseline & 121.93 & 8.391 & 121.80 & 9.178 & 122.70 & 7.944 \\
\hline 5 Min & 121.57 & 8.850 & 121.80 & 9.415 & 122.53 & 8.386 \\
\hline 10 Min & 123.10 & 9.061 & 122.83 & 7.729 & 122.73 & 8.128 \\
\hline $15 \min$ & 125.9 & 181.989 & 123.13 & 6.882 & 122.47 & 8.046 \\
\hline 30 Min & 118.13 & 9.336 & 122.10 & 7.097 & 122.33 & 7.503 \\
\hline 45 Min & 117.77 & 11.584 & 121.13 & 7.477 & 122.60 & 7.686 \\
\hline 60 Min & 115.53 & 12.065 & 120.73 & 8.060 & 122.00 & 7.316 \\
\hline 90 Min & 115.53 & 11.705 & 119.70 & 7.706 & 121.27 & 5.789 \\
\hline $120 \mathrm{Min}$ & 115.50 & 10.951 & 119.00 & 7.856 & 121.43 & 5.975 \\
\hline 6 Hrs. & 115.60 & 10.095 & 118.77 & 8.557 & 118.53 & 18.390 \\
\hline 12 Hrs. & 116.93 & 10.709 & 119.20 & 8.576 & 122.40 & 6.775 \\
\hline 18 Hrs. & 117.83 & 9.728 & 118.20 & 8.277 & 121.80 & 7.092 \\
\hline $24 \mathrm{Hrs}$. & 119.33 & 9.817 & 119.53 & 8.233 & 122.47 & 6.842 \\
\hline
\end{tabular}

Table showing Systolic blood pressure (Mean \pm SD) among all three groups.

\begin{tabular}{|c|c|c|c|c|c|c|}
\hline \multirow{2}{*}{ DBP } & \multicolumn{2}{|c|}{ GROUP I } & \multicolumn{2}{|c|}{ GROUP II } & \multicolumn{2}{|c|}{ GROUP III } \\
\hline & Mean & \pm SD & Mean & \pm SD & Mean & \pm SD \\
\hline Baseline & 74.70 & 8.086 & 75.37 & 8.969 & 76.73 & 8.513 \\
\hline 5 Min & 72.53 & 8.866 & 75.73 & 9.864 & 74.67 & 7.671 \\
\hline $10 \mathrm{Min}$ & 72.60 & 9.758 & 76.17 & 9.952 & 74.67 & 8.652 \\
\hline 15 Min & 71.33 & 9.998 & 75.37 & 10.836 & 74.00 & 8.103 \\
\hline $30 \mathrm{Min}$ & 72.13 & 10.075 & 73.87 & 10.569 & 74.73 & 8.982 \\
\hline $45 \mathrm{Min}$ & 72.53 & 10.451 & 73.50 & 9.623 & 73.53 & 8.815 \\
\hline 60 Min & 72.87 & 10.030 & 72.73 & 9.762 & 75.00 & 8.250 \\
\hline 90 Min & 72.33 & 9.308 & 72.90 & 9.571 & 74.67 & 8.360 \\
\hline $120 \mathrm{Min}$ & 72.33 & 8.790 & 72.80 & 9.535 & 74.73 & 8.060 \\
\hline 6 Hrs. & 72.20 & 8.244 & 73.20 & 9.579 & 74.27 & 8.233 \\
\hline 12 Hrs. & 71.47 & 7.682 & 73.20 & 8.560 & 74.00 & 7.861 \\
\hline 18 Hrs. & 71.67 & 9.470 & 72.73 & 8.461 & 74.40 & 8.443 \\
\hline 24 Hrs. & 72.87 & 9.138 & 73.80 & 9.675 & 74.80 & 8.130 \\
\hline
\end{tabular}

Table 11: Showing Statistical Analysis of Diastolic Blood Pressure (Mm of Hg) Among Three Groups

Table showing diastolic blood pressure $(\mathrm{mmHg})(\mathrm{Mean} \pm \mathrm{SD})$ in three groups. 


\section{REFERENCES}

1. De Tran QH, Clemente A, Doan J, et al. Brachial plexus blocks: a review of approaches and techniques. Can J Anaesth 2007;54(8):662-674.

2. Ertug Z, Yegin A, Ertem S, Sahin N, Hadimioglu N, Dösemeci L, et al. Comparison of two different techniques for brachial plexus block: infraclavicular versus axillary technique. Acta Anaesthesiol Scand 2005;49(7):1035-1039.

3. Handoll HH, Koscielniak-Nielsen ZJ. Single, double or multiple injection techniques for axillary brachial plexus block for hand, wrist or forearm surgery. Cochrane Database Syst Rev. 2006;(1):CD003842.

4. Liisanantti O, Luukkonen J, Rosenberg PH. High-dose bupivacaine, levobupivacaine and ropivacaine in axillary brachial plexus block. Acta Anaesthesiol Scand. 2004;48:601-606. [PubMed].

5. Ivani G, DeNegri P, Conio A, Grossetti R, Vitale P, Vercellino $\mathrm{C}$, et al. Comparison of racemic bupivacaine, ropivacaine, and levo-bupivacaine for pediatric caudal anesthesia: effects on postoperative analgesia and motor block. Reg Anesth Pain Med. 2002;27:157-161. [PubMed].

6. Foster RH, Markham A. Levobupivacaine: a review of its pharmacology and use as a local anaesthetic. Drugs 2000;59(3):551-579.

7. Leone S, Di Cianni S, Casati A, et al. Pharmacology, toxicology and clinical use of new longacting local anesthetics, ropivacaine and levobupivacaine. Acta Biomed 2008;79(2):92-105.

8. Urbanek B, Kapral S. Levobupivacaine for regional anesthesia. A systematic review. Anaesthesist 2006;55(3):296-313.

9. Casati A, Borghi B, Fanelli G, Cerchierini E, Santorsola R, Sassoli V, et al. A double-blinded, randomized comparison of either $0.5 \%$ levobupivacaine or $0.5 \%$ ropivacaine for sciatic nerve block. Anesth Analg 2002;94(4):987-990.

10. O'Donnell BD, Iohom G. Regional anesthesia techniques for ambulatory orthopedic surgery. Curr Opin Anaesthesiol 2008;21(6):723-728.

11. Fuzier R, Fourcade O, Pianezza A, Gilbert ML, Bounes V, Olivier M. A comparison between double-injection axillary brachial plexus block and midhumeral block for emergency upper limb surgery. Anesth Analg 2006;102(6):1856-1858
12. Hickey R, Hoffman J, Ramamurthy S, MSN. A comparison of Ropivacaine $0.5 \%$ and bupivacaine $0.5 \%$ for brachial plexus block. Anesthesiology 1991;74:639-642.

13. McGlade DP, Kalpokas MV, Mooney PH, Chamley D, Mark $\mathrm{AH}$, Torda TA: A comparison of $0.5 \%$ ropivacaine and $0.5 \%$ bupivacaine for axillary brachial plexus anaesthesia. Anaesth intensive care 1998;26(5):515-520.

14. Klien SM, Greengrass RA, Grant SA, et al. A comparison of $0.5 \%$ bupivacaine, $0.5 \%$ Ropivacaine and $0.75 \%$ Ropivacaine for interscalene brachial plexus block. Can J Anaesth 2001;48(4):375-378.

15. Hickey R, Candido KD, Ramamurthy S, et al. Brachial plexus block with a new local anaesthetic: $0.5 \%$ Ropivacaine. Can J Anaesth 1990;37:732-738.

16. Casati A, Fanelli G, Cappelli G, et al. A clinical comparison of Ropivacaine $0.75 \%$, Ropivacaine $1 \%$ or bupivacaine $0.5 \%$ for interscalene brachial block. EUR J anaesthesiol 1999;16(11):784-789.

17. Nagia Mohamed Abd EI Morti, Zeinab Bayoumy Youssef, Soaad Said Abd EL Aal, et al. 2006: Ropivacaine versus bupivacaine for interscalene brachial plexus block, pharmacological and clinical comparison. The Egyptian Journal of Hospital Medicine; 25:691-702.

18. Bertini $\mathrm{L}$, Tagarieollo V, Mancinin S, et al. $0.75 \%$ and $0.5 \%$ ropivacaine for axillary plexus block: A clinical comparison with $0.5 \%$ bupivacaine. Can J Anaesth 1999;(12):234-254.

19. Raeder JC, Drosdahl S, Klaastad O, et al. Axillary brachial plexus block with Ropivacaine $7.5 \mathrm{mg} / \mathrm{ml}$ : A comparison with bupivacaine $5 \mathrm{mg} / \mathrm{ml}$. Acta anaesthesiol scand 1999;43(8):794-798.

20. Casati A, Fanelli G, Albertin A, et al. Interscalene brachial plexus anaesthesia with either $0.5 \%$ Ropivacaine or $0.5 \%$ bupivacaine. Minerva Anesthsiol, 2000;66(1-2):39-44.

21. Eragiu A, Uzunlar H, Sener M, et al. A clinical comparison of equal concentration and volume of ropivacaine and bupivacaine for interscalene brachial plexus anaesthesia and analgesia in shoulder surgery: Reg Anesth pain med 2004 Nov-Dec; 20(6):539-43. 